\title{
RECREATIONAL DEVELOPMENT OF OLD LANDFILL: THE CASE STUDY OF GÓRKA ROGOWSKA LANDFILL IN ŁÓDŹ CITY, POLAND
}

\section{Andrzej Długoński *}

Faculty of Biology and Environmental Sciences, Department of Environmental Engineering, Cardinal Stefan Wyszyński University in Warsaw, Wóycickiego 1/3, 01-938 Warsaw, Poland

Article Info:

Received:

1 February 2018

Revised:

20 April 2018

Accepted:

20 June 2018

Available online:

30 June 2018

Keywords:

Landfill development

Green areas

Sport and recreational park

Design

Lodz city

\begin{abstract}
In recent years in Europe and the United States, there has been a noticeable increase in urban green areas, some of which are built on post-industrial areas, particularly those affected by unemployment and requiring broad structural change (Pancewicz, 2011). Decisions on the location of parks in degraded areas are mainly due to the lack of free space in the city (esp. in downtown zone). Therefore, they are beginning to be designed in suburban areas, often within larger complexes like forests, to protect open areas in suburbs of cities. These open areas are subjected to various activities (renovation, revitalization, reclamation, etc.), with the purpose of assigning them new functions in terms of development. Nowadays they are seen as an barren reserves that can contribute to improving the quality of life in the city and enhancing the attractiveness of urban areas and neighboring areas through the implementation of new investments. Among the degraded areas are landfill sites, which, due to the urban sprowl, are entering into conflict with neighboring areas (housing estate areas, open spaces like forests and arable areas), making it difficult for the environment and its inhabitants. One of the examples of such sites is Górka Rogowska in Łódź (Poland), the subject of presented case study. Unfortunately, because of many wrong attempt decisions this area has not been properly reclaimed and developed, and currently is still a social and environmental problem and a threat to the safety of residents. However, the above-mentioned landfill site has a valuable natural potential, which due to its convenient location can be used for tourism, recreation and therapeutic purposes. Thus, the proposed lanscape development can be a challenge to improve the condition of urban environment.
\end{abstract}

\section{INTRODUCTION}

Examination of waste dumping grounds and other degraded areas only in the context of environmental hazards seems to be inappropriate. In the course of time, these areas become not only a place of life for many plants and animals, but also they forge readable and original landscape forms, which affect significantly their environment (Kurowski, 1998; Siciński, 2001; Markuszewska, 2009; Pancewicz 2011; Długoński, 2012).

Among the publications devoted to technical methods of disposal such as biological utilization (Selivanovskaya et al., 2006; Das et al., 2015), energy and electric utilization (Rotheut and Quicker 2017), waste gasification / methane production (Behera et al., 2010; Zhen et al., 2016; Kormi et al., 2017; Zhao et al., 2017), characterization of landfill temperatures (Jafari et al., 2017), or waste management of urban and landfill areas in technical way (Teira-Esmatg- es and Flotats, 2003; Hui et al., 2006; Seadon, 2006; Weng ed., 2011; Slagstad and Bratteb $\emptyset, 2012$; Josimović et al., 2015; Silva ed., 2017), there is a short list of publications on residential aspects (Joos et al.1999; Kontos et al., 2005) as well as ecological landuse of the landfills (Siuta et al., 1983; Maciak, 1996; Gasidło, 1998; Koda et al., 1999; 1000 x Landscape Architecture, 2009; Pancewicz, 2011; Długoński, 2012; Pluta, 2014; Chen et al., 2017).

Nowadays, many of the old landfills are becoming increasingly important parts of significant sports and leisure complexes (Pancewicz, 2011; Długoński, 2012). Sometimes they consist of multisection areas as hotel, club, restaurant, sports hall, indoor swimming pool (e.g. Górka Rogowska landfill in Lodz, Poland), or horror park, fantasy park, thrill park, action studio, western city, colosseum, indian village, panoramic restaurant with terrace, military camp, jungle adventure, lunapark, water sports harbor, 
gravity jumping, mobile surfing installation (e.g. Górka Retkińska landfill in Lodz, Poland) and ice and roller skating, ski slope (e.g. Alpincenter in Bottrop, Germany), which often require high financial decisions and make such investments questionable. However, some of the undeveloped areas are also devoted to less costly facilities, which are often accomplished through the large and selfless involvement of the public. Thus, because the landfill sites are often ideally located in city's suburbies near main roads junction, the idea of transforming them only into recreational and smart sport parks, seems to be justified. They can offer residents a variety of activities such as horseback riding, cycling, golfing (e.g. Stockley Park in London, Great Britain) or walking in contact with the surrounding nature (San Giuliano metropolitan park in Venice, Italy). Another aspect is also an usage there selected ecological technologies with a low budget for their implementation (e.g. rockery with selected cover plants), for example protection of site slopes of constructional waste and sourrounding groundwaters (Górka Bemowska landfill design concept in Warsaw, Poland).

Eventually, the landfill areas are important for local residents and fulfill a variety of ecological services for users (Baur ed., 2014; Haase, 2014; Długoński and Szumański 2016a). Moreover, the presence of these objects in the landscape also provides cultural identity of the area and becomes a landmark enabling the simple location of other landscape elements (Lynch, 1960).

The subject of a paper is constructional waste named Górka Rogowska, located in the city of Łódź, Poland. The aim of the paper is to present the ecological ways of old landfill development. The scope of the paper is proper selection of urban plants and spatial land use to transform old landfill of constructional waste into recreational area. The presented paper is a continuation of the author's research on green infrastructure (Długoński, 2014, 2016, 2017; Długoński and Szumański, 2015, 2016a, 2016b) and degraded urban areas (Długoński, 2011, 2012) that require revitalization processes.

\subsection{Characteristic of study area}

The study area is landifill named Górka Rogowska, with previous waste dumping ground in Łódź city, numerous defective concrete plates used to built skyscrapers in Lodz city. They were stored there from the 60's to the 80 's of 20 C. In addition, waste materials derived from old buildings demolition, containing large amounts of debris, were stored. Waste building storage was completed in the early $80 \mathrm{~s}$. Due to the nearest housing estate area and a location of primary school, it was decided to cover the landfill with an anthropogenic soil.

\subsubsection{Study area location}

The Górka Rogowska ladfill is located in the north-eastern part of Łódź city (central Poland) in the suburban zone (Figure 1). The area of the landfill is 7 hectares with the sourrounding area of 20 hectares of open space sourronding the constructional waste (in total 27 hectares). The neighborhood (1-5 km) of the case study site are Łagiewnicki forest (1200 ha), service buildings (primary school, hospice and church) and single family housing estates. The area located near the expressway (road DK14: Sochaczew-Sieradz) and motorway junction (A1: Ostrava-Gdańsk / A2: Berlin-Warszawa).

\subsubsection{Study area land use}

The Górka Rogowska landfill is an open public space with three distinct inclined slopes, pedestrian-bicycle roads, and a viewing point. The sourrounding area under constructional waste consists of several meadows with natural trees and picnic places for outdoor games during the spring and summer season. The site is partly managed by the Municipality of Łódź city (landfill site). The sourrounding area of the landfill is mostly private or State Treasury property or it has unsettled legal status (APA Projekt Pracownia Architektoniczna 2007, InterSIT, 2017c). The study of conditions and directions of spatial development of the Łódź city (Studium, 2010) dedicates Górka Rogowska landfill as a strategic area, which is important element of functional structure of the city for creating sport and recreation city complex in the future. According to APA Projekt Pracownia Architektoniczna (2007) design concept and Długoński (2012) research, in November and December 2011 the minor renovation work of the landifll site was carried out. The surface of the paths has been replaced, and conrete slopes dehydration have been installed. At the top of the landfill small architectural elements (several benches, rubbish bins, wood barriers with a bicycle rack) has been built. It was decided to give up with rain protecting construction and sports fields under the landfill site. In addition, some of the wild vegetation that limit the view from the hill, has been cut. However, due to the limited budget, it was unable to complete all planned works. Actually, the main problem are still the eroding landfill slopes. Moreover, mainly in the north and east part of the landfill, the ground of slopes is unstable due to pedestrians and cyclists activities. Finally, many behavioral factors negatively affect the

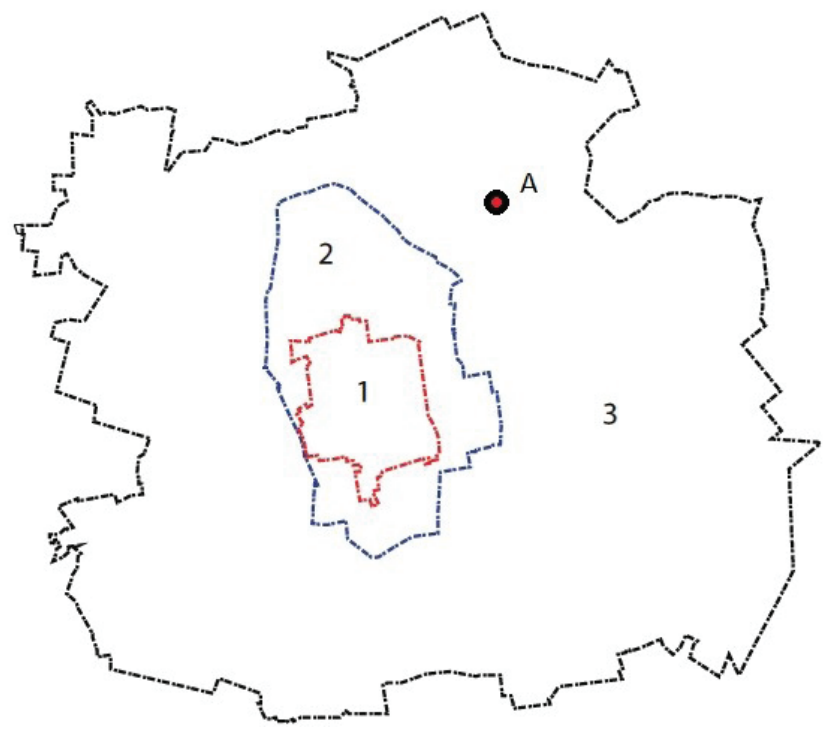

FIGURE 1: Location of Górka Rogowska landfill (A) in Łódź, Poland, 1-downtown zone, 2- residential zone, 3- suburban zone (own elaboration based on: Janiak, 2012; InterSIT, 2017b). 
technical condition of existing trees, small architectural elements and stability all the landill.

\section{METHODOLOGY}

The methodology consists of several steps. The first was studio research based on literature review.on degraded areas land development and their reclamation (Siuta ed., 1983; Maciak 1996; Pancewicz 2011; Długoński 2012) to select the most suitable solution for recreation of the case study. During this review objects located in cities suburban zone with different ways of their early function and landuse, were choosen.. Then, comparative analysis of development of old landfills was made (Długoński, 2012). It showed a large diversity of landfill sites in terms of their area, waste depositon type as well as the ways of their recreational development and activities for users (Table 1).

Transforming old landfill sites into new functional areas involves an introduction of recreational, sports and cultural activities and should take into consideration the social needs and the individual approach to each case.
The second step was field research with interview with the local community and scientists. The interview with residents of a nearby housing estate area (APA Projekt Pracownia Architektoniczna, 2007) showed their interest in creating a multifunctional park in the study area through practicing sports and active recreation (pro-health role); developing and expanding intellectual and cognitive horizons (cultural development role); and shaping civic attitudes, interest development and ecological education (pro-democracy role).

An additional interview with scientist Dr. Jan Ziomek (geologist) from the Faculty of Geography and Earth Sciences at University of Łódź, one of the few experts remembering the time of its building was conducted in November 2011 (Ziomek, 2011). Due to lack of materials and literature about the landfill, the scientit added most important information about the landfill formation and its development. According to this interview, numerous defective concrete plates, used to build skyscrapers in Lodz city, were stored from the 60's to the 80's of 20th Century. Waste materials derived from old buildings demolition, containing large

TABLE 1: Landfills development of selected landfill sites in Europe (Gasidło, 1998; Koda et al., 1999; 1000 x Landscape Architecture, 2009; Pancewicz, 2011; Długoński 2012; Pluta, 2014).

\begin{tabular}{|c|c|c|c|c|c|c|c|c|c|}
\hline No. & Landfill & Year of build & $\begin{array}{l}\text { Total area } \\
\text { (ha) }\end{array}$ & $\begin{array}{c}\text { City's } \\
\text { localization }\end{array}$ & $\begin{array}{l}\text { Waste } \\
\text { depositon } \\
\text { type }\end{array}$ & $\begin{array}{l}\text { Leasure } \\
\text { traffiic type }\end{array}$ & $\begin{array}{l}\text { Land use } \\
\text { develop- } \\
\text { ment }\end{array}$ & Land use elements & $\begin{array}{c}\text { Users } \\
\text { activities }\end{array}$ \\
\hline 1 & $\begin{array}{l}\text { Górka } \\
\text { Rogowska in } \\
\text { Łódź, Poland }\end{array}$ & $\begin{array}{l}70 \text { ' of } 20 \mathrm{C} \\
\text { (previous } \\
\text { design } \\
\text { concept of } \\
\text { another de- } \\
\text { sign studio) }\end{array}$ & 27 & Suburbies & $\begin{array}{l}\text { Construc- } \\
\text { tional waste }\end{array}$ & $\begin{array}{l}\text { Weakly/ } \\
\text { yearly }\end{array}$ & $\begin{array}{l}\text { sport and } \\
\text { recreational } \\
\text { park com- } \\
\text { plex }\end{array}$ & $\begin{array}{l}\text { Hotel, club, indoor } \\
\text { swimming pool, } \\
\text { sports hall, sports } \\
\text { fields, recreation } \\
\text { ponds, playgrounds, } \\
\text { lookout terraces, bike } \\
\text { trails, rainforests, } \\
\text { barbecue squares }\end{array}$ & $\begin{array}{l}\text { Cycling, } \\
\text { ball games, } \\
\text { walking, } \\
\text { swimming, } \\
\text { leisure, } \\
\text { fun and } \\
\text { games }\end{array}$ \\
\hline 2 & $\begin{array}{c}\text { Górka } \\
\text { Retkińska in } \\
\text { Łódź, Poland }\end{array}$ & $\begin{array}{l}70 \text { ' of } 20 \mathrm{C} \\
\text { (design con- } \\
\text { cept 2010) }\end{array}$ & 35 & Suburbies & $\begin{array}{l}\text { Construc- } \\
\text { tional and } \\
\text { compost } \\
\text { waste }\end{array}$ & $\begin{array}{l}\text { Weakly/ } \\
\text { yearly }\end{array}$ & $\begin{array}{l}\text { amusement, } \\
\text { recreational } \\
\text { and sport } \\
\text { park com- } \\
\text { plex }\end{array}$ & $\begin{array}{l}\text { Horror park, fantasy } \\
\text { park, thrill park, action } \\
\text { studio, western city, } \\
\text { colosseum, indian } \\
\text { village, panoramic } \\
\text { restaurant with terrace, } \\
\text { military camp, jungle } \\
\text { adventure, lunapark, } \\
\text { water sports harbor, } \\
\text { gravity jumping, mo- } \\
\text { bile surfing installation, } \\
\text { alleys with trees }\end{array}$ & $\begin{array}{l}\text { Extremal } \\
\text { and pro- } \\
\text { fessional } \\
\text { sports or } \\
\text { hobbies, fun, } \\
\text { cycling, } \\
\text { walking } \\
\text { didactics }\end{array}$ \\
\hline 3 & $\begin{array}{c}\text { Górka } \\
\text { Bemowska } \\
\text { in Warsaw, } \\
\text { Poland }\end{array}$ & $\begin{array}{c}1961(\mathrm{de}- \\
\text { sign concept } \\
2011)\end{array}$ & 32 & Suburbies & $\begin{array}{l}\text { Industrial } \\
\text { and com- } \\
\text { post waste }\end{array}$ & $\begin{array}{l}\text { Weakly/ } \\
\text { yearly }\end{array}$ & $\begin{array}{l}\text { sport and } \\
\text { recreational } \\
\text { park }\end{array}$ & $\begin{array}{c}\text { Ski slope with } \\
\text { downhill runs, sports } \\
\text { and walking routes, } \\
\text { rockery with selected } \\
\text { cover plants }\end{array}$ & $\begin{array}{l}\text { Skiing, } \\
\text { cycling, } \\
\text { walking }\end{array}$ \\
\hline 4 & $\begin{array}{l}\text { Stockley } \\
\text { Park in Lon- } \\
\text { don, Great } \\
\text { Britain }\end{array}$ & 1985 & 450 & Suburbies & $\begin{array}{l}\text { Municipal } \\
\text { waste and } \\
\text { gravel }\end{array}$ & $\begin{array}{l}\text { Weakly/ } \\
\text { yearly }\end{array}$ & $\begin{array}{l}\text { recreational } \\
\text { park (land- } \\
\text { cape) }\end{array}$ & $\begin{array}{l}\text { Water reservoirs, } \\
\text { horse riding routes, } \\
\text { cycle tracks, gym } \\
\text { area, meadow for golf } \\
\text { practice, walking and } \\
\text { health paths, groups } \\
\text { of trees and shrubs }\end{array}$ & $\begin{array}{l}\text { Horseback } \\
\text { riding, } \\
\text { cycling, } \\
\text { golfing, } \\
\text { walking }\end{array}$ \\
\hline 5 & $\begin{array}{l}\text { Alpincenter } \\
\text { in Bottrop, } \\
\text { Germany }\end{array}$ & N.A. & 30 & Suburbies & $\begin{array}{l}\text { Construc- } \\
\text { tional waste }\end{array}$ & $\begin{array}{l}\text { Weakly/ } \\
\text { winter } \\
\text { season }\end{array}$ & ski center & $\begin{array}{l}\text { Ski slopes, toboggan } \\
\text { runk, groups of trees } \\
\text { and shrubs }\end{array}$ & $\begin{array}{c}\text { Ice and } \\
\text { rolller skiing, } \\
\text { skateboard- } \\
\text { ing }\end{array}$ \\
\hline 6 & $\begin{array}{l}\text { San Giuliano } \\
\text { Metropolitan } \\
\text { Park in Ven- } \\
\text { ice, Italy }\end{array}$ & N.A. & N.A. & Suburbies & $\begin{array}{l}\text { Muninipal } \\
\text { waste }\end{array}$ & $\begin{array}{l}\text { Weakly/ } \\
\text { yearly }\end{array}$ & $\begin{array}{l}\text { recreational } \\
\text { park (land- } \\
\text { cape) }\end{array}$ & $\begin{array}{l}\text { Water reservoirs and } \\
\text { channels, recreational } \\
\text { meadows, squares, } \\
\text { groups of trees and } \\
\text { shrubs }\end{array}$ & $\begin{array}{l}\text { Walking and } \\
\text { contempla- } \\
\text { tion }\end{array}$ \\
\hline
\end{tabular}


amounts of debris, were also delivered. Waste building storage was completed in the early $80 \mathrm{~s}$. Due to the nearest housing estate area and a location of primary school, it was decided to cover the landfill with an anthropogenic soil..

Then the vegetation inventory (Długoński, 2012; APA Projekt Pracownia Architektoniczna 2007) shows that the area needs to be supplemented with cover vegetation and predisposition to strengthen the slope of the landfill. The colncusion is the new native species of trees and shrubs located in groups at the bottom of the landfill (urban park designing idea, is needed).

The storage stability analysis of Computer Thermography Laboratory DMCS (2011) by thermal imager, was made. The DMCS report confimed data obtained during the interview (Ziomek, 2011) that the landfill was constructed of buildup materials and debris. Because no hazardous materials were found, the facility does not pose a threat to the natural environment.

The landscape connections and terrain shaping analysis showed that the site is valuable view point of Łódź city and the Łódzkie region. Therefore, an important aspect is an arrangement of existing views from the top of the hill (panorama of Łódź city and Łagiewnicki forest) as well as inside the study area.

The users activities analysis showed that the landfill area is mainly used on weekends in the spring and summer. The users are mainly cyclists (downhill cyclists activities) and local residents (walking activity) as well as families and children from nearest school (outdor games). The conclusion is the facility should be diversified with the emphasis on the expansion of sports and recreational activities that could relieve the neighboring Łagiewniki forest from excessive usage (Długoński, 2012). The acoustic climate analysis showed that noise standards (over $65 \mathrm{~dB}$ ) were permissible (InterSIT, 2017a). For this reason, it is necessary to rebuild the buffer zone with insulating vegetation on the side of high traffic streets.

The final step was sudio design scenarios base on five different scenarios of future landifill development (Długoński 2012). The scenarios diifer spatial arrangement and landscape eleemnts location. Also the programme for each scenario was preprared. The selecged programme based on recreational purposes with properly selected urban vegetation used in difficult urban conditons (like near roads, city centre and deep slopes).

\section{RESULTS AND DISCUSSION}

\subsection{Future landuse of Górka Rogowska landfill}

The concept of Górka Rogowska development is a result of author's comprehensive research on functional use of reclaimed (previously degraded) areas and could be included into general green infrastructure concept of Łódź city.The aim of Górka Rogowska landfill design concept is to maintain the original forest and recreational character of the study area in spatial layout composition by creating urban park for different user's activities (Figure 2).

Due to the area location in suburban zone near Łagiewnicki forest, it was decided to maintain the land- scape and nature forest character of the area and creating there forest recreation centre. At the bottom of the landfill, the park design was aimed at creating many recreational meadows with natural groups of trees and shrubs, which provides more favorable conditions for the vegetation development, richer plastic effects displaying natural colour plants, wavy terrain as well as greater sense of security and comfort for park users. Because of the fact that the landfill is currently the only viewing point in suburban zone of the Łódź city, it is important to introduce the viewpoints (wooden terraces). For this reason, it was decided to create or maintain distant views (sight axes), which ended with characteristic management elements (i.e. ponds, church, school, hotel located in landfill sourrounding area), or group of high colour trees. The interior views of the study area are shaped by removing less valuable plants showing views and exposing particularly attractive spaces of the site (meadows). In addition, it is expected to gradually replenish the aging trees (Acer negundo, Populs sp., Fraxinus excelsior, Prunus cerasifera) with more valuable and long-lasting plant species referring to local environmental conditions (Pinus sp., Tilia sp., Quercus sp.) in the future. It is also envisaged to shape the top of the landfill with sufficiently stabilized soil (originating from the excavation of the proposed ponds in sourrounding area) and consolidation and correction of landfill slopes and usage of selected medium-sized bushes and cover plants used in slope constructions in urban green areas These are well-drained, quickly growing and long-lived plants with extensive root system and low care requirements, such as: Berberis thunbergii, Aeuga reptans, Asarum europaeum, Cornus mas, Corylus avellana, Forsythia $x$ intermedia, Hedera helix, Lonicera xylosteum, Pachysandra terminalis, Sambucus nigra, and Vinca minor. It is worth emphasizing here that another important aspect of the design is creation of suitable drainage system of the landfill that consists of a living beaver drain, especially in the places of the largest runoff on the site slopes. Fascias are attached to healthy woody plant cuttings, slanting diagonally into the soil through the fascia. Such drainage system has a far broader and deeper impact, especially on difficult to dehydrate slopes than ordinary concrete gutters, currently used along sloping parks paths. Additionally it should be noted that the existing landfill slopes can serve as a great area for cycling in spring, summer and autumn season.

The concept assumes to build of three bicycle tracks at the landfill. The tracks, due to the high incline of the elevation (20-50 degrees), will only be made of anthropogenic soil, strewn with gravel. These will consist of properly formed embankments and muld, which vary difficulty level of the routes. The routes will also be completed with profiled bends due to the need to brake the bikes at high speed. However, in winter season the tracks are designing for skiing and toboggan runs.

What is more, under the landfill, the concept is to introduce rehabilitation trails for sport activities (health path, gym area, and meadow for golf practice) with dense plants to make comfort zones.

The design idea is also to introduce an educational path with information boards about fauna and flora adjacent to 


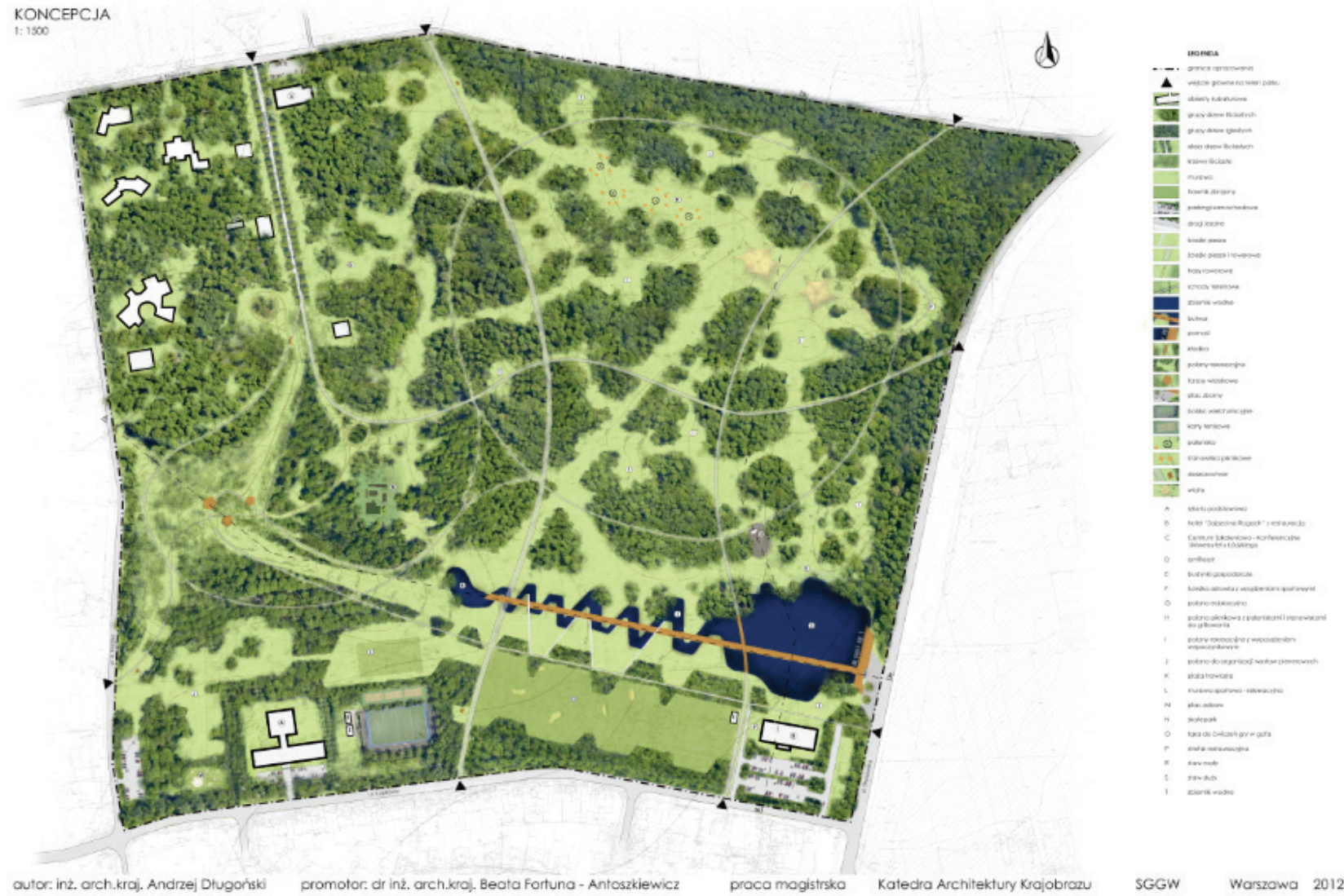

FIGURE 2: Land use design concept of Górka Rogowska landfill, as urban park (Długoński 2012).

the tagiewnicki forest along with stopping points equipped with seats. This site will be able to serve as a point of field lesson for school children.

Becuse of the deficiency of water reservoirs in Łódzkie region the idea of two ponds connected by a geometric channel with a boulevard and usage of water plant species to cleaning the environment was considered. These facilities are able to gather rainwater from the site and landfill and fulfill an ornamental and recreational functions with the extension of the sport function (canoeing, fishing, water bicycles etc).

Due to the observed exceeded noise standards of the area near expressway, creating an buffer zone (groups of trees and shrubs) to protect the area from excessive noise is proposed. These plants are also important in air purification of the planned site (phytoremediation).

As a result, the proposed design concept of recreational development of previous landfill area, expose natural values of the site, protect the environment, and make the object more attractive for different users.

\subsection{Development of old landfill as a design challenge}

The analysis of Górka Rogowska landfill has shown reclaimed area with high natural potential, however, not properly utilized. The improveing of the visual layout of the site by ecological utilization and adaptation of the site to users needs by appropriate spatial development seems to be very important there.
A literature review of the landfill development approaches shows the wide variety of proposed program elements (Gasidło, 1998; Koda et al., 1999; 1000 x Landscape Architecture, 2009; Pancewicz, 2011; Długoński 2012; Pluta, 2014). However, only a part of them (e.g. forest nature character of the site, recreational facilities for various types of recreation, terraces for observation, bicycle paths, and walking paths) was managed to introduce in the Górka Rogowska landfill design described in this work. On the one hand, economic development seems to be optimal and do not involve high financial investment, such as thrill park, action studio, western city, colosseum, indian village, military camp etc. presented in Górka Retkińska landfill future development. For the same reason, in spite of the favorable shape of landfill, it was not decided to adapt it fully to the skiing areas (e.g. Alpincenter). However, on the basis of these examples, it was managed to adapt the area to cross-country skiing and toboggan runs in the winter. Besides, the ideas used e.g. in Stockley Park were the inspiration for introducing places to practice various types of sport (e.g. cycle tracks, health path, gym area, and meadow for golf practice). These elements proved to be valuable in terms of landfill site program components, like level difficulty of cycling routes. Furthermore, due to existing location of the Górka Rogowska landfill area, they could find a solution in the presented design concept (landfill as urban park area). In addition to the recreational and sport development of the site, it was decided to pre- 
serve existing valuable plants and create group of vegetations as well as introduce missing cover plants assuming that the vegetation in this area would be an important element of the stability and purification of the whole system. Introduction of buffer zone in the form of vegetation on the boundary allows the area to be quieted and cleaner for park users.

According to presented methodology, it is possible to draw conclusions about current needs of the local inhabitants (society) and to formulate the program objectives of site development. Thus, based on it a general idea of the concept is: the site should operate yearly and offer many opportunities for spending free time by introducing different elements of recreational development tailored to the needs of different users. Moreover, interviews with experts are a valuable addition to the literature review in the absence of essential information or can confirm the credibility of other information sources or field studies (e.g. Computer Thermography Laboratory DMCS, 2011).

During the studio research and design process, various possibilities of land development were taken into account. An interesting approach, very common in Western Europe is vegetable gardens known also as pocket parks, where the residents of the estate can plant vegetables together. It is good toll used to integrate residents. There is the question, is the landfill site a good place for growing vegetables? If the soil and environment is not hazardous the anser is yes. However, the usage of the study area for vegetable production seems to be unjustified. Firstly, the area is surrounded by a single-family residential housing, where both residents and landfill users have their own backyard gardens. In addition, the idea of common vegetable gardens in the Polish landscape is problematic and such designs often do not work well. On the one hand, plants are often destroyed and not respected by local communities, especially neglected people, which are many in Lodz city. On the other hand, there is a grat opportunity of employment poor people from the city center and suburbies to handle the holiday development area rather than inducing them to run vegetable gardens. Another variant of area design focused on the usage of ornamental plants resistant to difficult urban conditions, including slopes, which seems to be a priority in such a case study, bearing in mind that the area is neglected and overgrown with plants, which poses a health risk to users.

The final concept of Górka Rogowska is principally based on transforming the area into a forest recreation center, with numerous recreational meadows for various recreation types, sports facilities and nature trails, which seems optimal and do not involve the excessive financial expenditures. For the same reason and having regard to the hilly terrain, it was proposed to adapt it partly to skiing (e.g. ski center in Botropp in Germany and Górka Bemowska landfill in Warsaw, Poland) and partly to another sports: golf, jogging, fishing, sailing etc. (e.g. Stockley Park in London, Great Britain), downhill (e.g. Poniatowski Park in Łódź). In terms of spatial aspects it was decided to preserve existing natural structures assuming that largely growing urban plants on this area will be an important element in the stability of the ecological system.
What is also important, soil research seems to be an important issue especially in the context of the selection of the species to pollution issue of the Lodz city and it should certainly be the subject of further research. This should be accompanied by a further step of technical design, with dimensioning and arranging of specific plant species. However, the aim of the research, was to assume the possibility of land development through the usage of plants and recreational elements that can improve the properties of study area by fully usage of its natural potential. It seems that the presented concept of old landfill development can be used as an example in other degraded areas for recreational purposes. Therefore, spatial and ecological solutions presented in this research may find a wider application in other case studies, also those strictly created from urban waste.

\section{CONCLUSIONS}

The article presents selected ecological solutions for constructional waste landfills recreational development (so called urban park) as an impotant future element of the city's green infrastructure. The ecological development way of municipal landfill development through by selection of plant species to constructional waste stability protection fulfills a role in purification of the cities natural environment. Moreover, the introduction of adequate land use elements in landfill's spatial management through proper landscape development of municipal landfills improves difficult inhabitants living conditions and prevents adjacent urban open areas from progressive degradation caused by unorganized recreational activities. The presented analyses of landfill sites may be helpful in defining ecosystem services of cities degraded areas. The research on ecological utilization of landfill sites, developed on the example of Górka Rogowska landfill, can inspire further research on other objects, and support interdisciplinary research in the field of ecological engineering and waste management, as well as, urban landscape planning. Finally, the research may also fulfiill an important role in supporting and developing tasks of local social and ecological organizations by identifying the importance and benefits of the cities degraded areas as a places for sport, recreation and social well-being.

\section{AKNOWLEDGEMENTS}

The author acknowledges APA Projekt Pracownia Architektoniczna and Pracownia Termografii Komputerowej DMCS, for providing data to perform a vital analysis.

\section{REFERENCES}

1000 x Landscape Architecture (2009). Verlagshaus Braun, 645. APA Projekt Pracownia Architektoniczna. (2007). Koncepcja zagospodarowania zespołu rekreacyjno - edukacyjnego w rejonie ulic Strykowskiej, Łupkowej, Książka i Rogowskiej w Łodzi Opracowanie konkursowe (Development of multi-recreational and educational center design in the area of Strykowska, Łupkowa, Książka and Rogowska streets in Łódź Design competition.

Baur J.W.R. ed. (2014). Urban Parks and Attitudes about Ecosystem Services: Does Park Use Matter? Vol. 32, 4/2014. Journal of Park and Recreation Administration, Sagamore. 
Begemann W., Schiechtl H.M. (1999). Inżynieria ekologiczna W budownictwie wodnym (

Environmental engineering in water construction). Arkady Warszawa, 142- 155.

Behera S.K., Park .M., Kim K.H.,Park H.S. (2010). Methane production from food waste leachate in laboratory-scale simulated landfill. Waste Management, vol. 30, Issues 8-9, August-September 2010, 1502-1508.

Brand E., de Nijs T.C.M., Dijkstra J.J. and Comans R.N.J. (2016). A novel approach in calculating site-specific aftercare completion criteria for landfills in The Netherlands: Policy developments. Waste Management, vol. 56, October 2016, 255-261.

Chen X.W., Wong J.T.F., Leung O.W.A, Ng Ch.W.W., and Wong M.H. (2017). Comparison of plant and bacterial communities between a subtropical landfill topsoil 15 years after restoration and a natural area. Waste Management, vol. 63, May 2017, 49-57.

Computer Thermography Laboratory DMCS (Pracownia Termografii Komputerowej DMCS) (2011). Raport z rekonesansu w sprawie badania termograficznego obiektu pn. Górka Rogowska z dn.15.06.2011. Politechnika Łódzka

Das O., Sarmah A.K., and Bhattacharyya D. (2015). A novel approach in organic waste utilization through biochar addition in wood/polypropylene composites. Waste Management, vol. 38, April 2015, 132-140.

Długoński A. (2012). Land use concept of the Rogowska Hillock recreation and sports park on the foreground of the $Ł a g i e w n i k i$ Forest in Łódź, Poland. MSc thesis, WULS-SGGW, Wasaw, 1-89.

Długoński A. (2014). Premises for the developmental principles of green infrastructure, a case study: Lodz city, Poland in: Kabisch N. (Ed.) Human-environmental interactions in cities : challenges and opportunities of urban land use planning and green infrastructure, Cambridge Scholars Publishing, 47-65.

Długoński A. (2016). Pro-ecological premises for the developmental principles of green areas, a case study: Lodz City, Poland. PhD thesis, WULS-SGGW, Warsaw, 1-503.

Długoński A. (2017). Assumptions for the analysis method of green infrastructure in big cities in: E. Węcławowicz-Bilska, New concepts of urban planning, vol.5. Social, functional and economic issues, Monograph 549, Tadeusz Kosciuszko Cracow University of Technology, Kraków, 37-62 (in press).

Długoński A., Szumański M. (2015). Analysis of green infrastructure in Lodz, Poland. Journal of Urban Planning and Development, vol. 3/2015, 1-9.

Długoński A., Szumański M. (2016a). Eco-urban atlas of green infrastructure in Lodz, Poland Green areas of downtown. ŁTN, Łódź, 1-303.

Długoński A., Szumański M. (2016b). Green infrastructure in city spacial policy in: T. Bradeckiego. ed. Mieszkać w mieście : wyzwania współczesności, vol.2. Politechnika Śląska, Gliwice, 121-129 (http://repolis.bg.polsl.pl/Content/40486/2017_03_RMWtom2. pdf) (accessed 08.06.16).

Gasidło K. (1998). Problemy przekształceń terenów poprzemysłowych (Problems of transformation of post-industrial areas). Zeszyty Naukowe Politechniki Śląskiej, vol. 1408/37, Architektura, Politechnika Śląska, IV Forum Architektury Krajobrazu, Katowice, 111-113.

Haase D. ed. (2014). A quantitative review of urban ecosystem service assessments: concepts, models, and implementation. Ambio. 2014 May;43/4,413-33.

Hui Y., Li'ao W., S. Fenwei, and Gang H. (2006). Urban solid waste management in Chongqing: Challenges and opportunitiesOriginal Research Article Waste Management, vol. 26, Issue 9, 2006, 10521062.

InterSIT. (2017a). Acoustic map o Łódź city (Mapa hałasu Łodzi). (http://akustyczna.mapa.lodz.pl/) (accessed 05.06.16).

InterSIT. (2017b). Ortophotomap of Łódź city (Ortofotomapa Łodzi). (http://mapa.lodz.pl/3/rest/services/OGC/Ortofotomapa/MapServer/WMTS?) (accessed 05.06.16).

InterSIT. (2017c). Plots ownership structure map of Łódź city (http:// gis2.mapa.lodz.pl/flexviewers/wlasnosc/) (accessed 05.06.16).

Jafari N.H., Stark T.D. and Thalhamer T. (2017). Spatial and temporal characteristics of elevated temperatures in municipal solid waste landfills. Waste Management, vol. 59, January 2017, 286-301.

Janiak M. (2012). Strategia przestrzennego rozwoju Łodzi jako polityka sektorowa Strategii zintegrowanego rozwoju Łodzi 2020+ (Spatial development strategy of Łódź as a sectoral policy of Łódź Integrated Development Strategy 2020+) (http://www.uml.lodz.pl/get. php?id=3681) (accessed 05.06.16).
Joos W., Carabias V., Winistoerfer H. and Stuecheli A. (1999). Social aspects of public waste management in Switzerland. Waste Management, vol. 19, Issue 6, October 1999, Pages 417-425.

Josimović B., Marić I., Milijić S. (2015). Multi-criteria evaluation in strategic environmental assessment for waste management plan, a case study: The city of BelgradeOriginal Research Article Waste Management, vol. 36, February 2015, 331-342.

Koda E., Pachuta K., and Wojarska I. (1999). Possibility of ecological remediation of old sanitary landfill. Agricultural University, Warsaw (Poland). Dept. of Geotechnics. Abstract (http://agris.fao. org/agris-search/search.do?recordID=PL2000001015) (accessed 05.06.16).

Kontos T. D., Komilis D.P. and Halvadakis C. P. (2005). Siting MSW landfills with a spatial multiple criteria analysis methodology. Waste Management, vol. 25, Issue 8, October 2005, 818-832.

Kormi T., Ali N.B.H., Abichou T., and Green R. (2017). Estimation of landfill methane emissions using stochastic search methodsOriginal Research Article Atmospheric Pollution Research, vol. 8, Issue 4, July 2017, 597-605.

Kurowski J. (1998). Zagospodarowanie środowiska przyrodniczo-gegraficznego (Management of the natural and geographic environment of PKWt) in: Kurowski J (Ed.) Park Krajobrazowy Wzniesień Łódzkich, EKO-WYNIK, Łódź, 14-142.

Lynch K. (1960). The image of the city, MIT Press, Cambridge.

Maciak F. (1996). Ochrona i rekultywacja środowiska (Environmental protection and reclamation). WULS-SGGW, Warszawa, 303-306.

Marczyński S. (2009). Stosowanie roślin okrywowych (Use of ground cover plants) in: Materiały z seminarium II Wiosennej Wystawy Szkółkarskiej Mazowiecka zieleń - jakość i asortyment, Pęchcin k..Ciechanowa, 13-21.

Markuszewska I. (2009). Możliwości i ograniczenia zagospodarowania nieużytków poprzemysłowych in: Problemy Ekologii Krajobrazu vol. XXIV. Problemy środowiska przemysłowego terenów poprzemysłowych, UAM, Poznań, 17-23.

Pancewicz A. (2011). Środowisko przyrodnicze w odnowie krajobrazu poprzemysłowego (Natural environment in the renovation of post-industrial landscapes). Politechnika Śląska, Gliwice, 133-139.

Pluta K. (2014). Przestrzenie publiczne miast europejskich projektowanie urbanistyczne (Public spaces of european urban designs) Oficyna Wydawnicza Politechniki Warszawskiej, Warszawa, 162163.

Rotheut M., and Quicker P. (2017). Energetic utilisation of refuse derived fuels from landfill mining. Waste Management, vol. 62, April $2017,101-117$

Seadon J.K. (2006). Integrated waste management - Looking beyond the solid waste horizonReview Article Waste Management, vol. 26, Issue 12, 2006, Pages 1327-1336.

Selivanovskaya S.Y. and Latypova V.Z. (2006). Effects of composted sewage sludge on microbial biomass, activity and pine seedlings in nursery forest. Waste Management, vol.26, Issue 11, 2006, $1253-1258$

Siciński J. (2001). Historia Lasu Łagiewnickiego (History of the Lagiewniki Forest) in: Kurowski J. (Ed.) Szata roślinna Lasu Łagiewnickiego w Łodzi (Vegetation cover of Łagiewnicki Forest in Lodz), Wydział Ochrony Środowiska Urzedu Miasta Łodzi, Katedra Geobotaniki i Ekologii Roślin UŁ, Łódź, 15-21.

Silva A., Rosano M., Stocker L., and Gorissen L. (2017). From waste to sustainable materials management: Three case studies of the transition journey. Review Article Waste Management, Volume 61 March 2017, 547-557.

Siuta J., Wasiak G., Litwin B. (1983). Zasady tworzenia stref ochronnych wokół wysypisk odpadów komunalnych (The creation of protective homes around the landfill of municipal waste) in: F. Maciak (1996). Ochrona i rekultywacja środowiska (Environmental protection and reclamation), WULS-SGGW, Warszawa, 303- 306.

Slagstad H., and Bratteb $\varnothing$ H. (2012). LCA for household waste management when planning a new urban settlement. Waste Management vol. 32, Issue 7, July 2012, 1482-1490.

Studium (2010). Studium uwarunkowań i kierunków zagospodarowania przestrzennego miasta Łodzi (Study of conditions and directions of spatial development of the city of Lodz), Miejska Pracownia Urbanistyczna w Łodzi, Łódź, 180.

Teira-Esmatges M.R., Flotats X. (2003). A method for livestock waste management planning in NE Spain. Waste Management, vol. 23, Issue 10, 917-932. 
Weng Y.Ch., Fujiwara T. (2011). Examining the effectiveness of municipal solid waste management systems: An integrated cost-benefit analysis perspective with a financial cost modeling in TaiwanOriginal Research Article Waste Management, vol.31, Issue 6, June 2011, 1393-1406.

Ziomek J. (2011). Interview with Dr. Jan Ziomek (geologist) on the history and development of the study area in Faculty of Geography and Earth Sciences at University of Łódź, Poland.

Zhao R., Xi B., Liu Y., Su J. and Liu S. (2017). Economic potential of leachate evaporation by using landfill gas: A system dynamics approach, Conservation and Recycling, vol. 124, September 2017, 74-84.

Zhen X., Rong L., Ng W.Ch., Ong C., Baeg G.H., Zhang W., Lee S.N., Li S.F.Y., Dai Y., Tong Y.W., Neoh K.G. and Wang Ch.H.(2016). Rapid toxicity screening of gasification ashes. Article Waste Management, vol. 50, April 2016, 93-104. 